\title{
METODE MIND MAPPING DALAM PENGEMBANGAN TOPIK PENELITIAN PAJAK PERTAMBAHAN NILAI (PPN)
}

\author{
Nurlita Sukma Alfandia \\ Fakultas Ilmu Administrasi, Universitas Brawijaya \\ Email: nurlita.sukma@gmail.com
}

\begin{abstract}
Tax research has now developed. The many topics of research outside of tax used as indicators of the importance of tax research are associated with other disciplines. Some approaches can be used in tax research. The approach includes multidisciplinary, interdisciplinary and intradisciplinary. Each approach has weaknesses and strengths in developing tax research in the future. This study aims to map tax research in international online journals during 2008 - 2018 or for approximately 11 years. The research period is limited to knowing the development of research topics used.This type of research is qualitative with a descriptive approach. Qualitative descriptive is taken because it fits the research objectives. Data retrieval is done by library and internet studies. The research data used are international online journals that have been submitted during 2008 - 2018. Sources of international online journals include sciencedirect, proquest, jstor, emeraldinsight, and other international online journal websites. The results of data collection were obtained as many as 183 online research journals.Based on the results of the analysis carried out, information was obtained on research topics covering economics, accounting, law, policy, public interest, information systems, and other topics. Another topic is the topic of tax research other than Value Added Tax.
\end{abstract}

Keywords: Mapping, Value Added Tax, Multidiciplinary, Intrediciplinary, Intradiciplinary, and Mind Mapping.

\begin{abstract}
ABSTRAK
Penelitian perpajakan kini telah mengalami perkembangan. Banyaknya topik penelitian di luar pajak yang digunakan menjadi indikator pentingnya penelitian perpajakan dikaitkan dengan disiplin ilmu lainnya. Beberapa pendekatan dapat digunakan dalam penelitian perpajakan. Pendekatan tersebut meliputi multidisiplin, interdisiplin, dan intradisiplin. Masing-masing pendekatan memiliki kelemahan dan kekuatan dalam mengembangkan penelitian perpajakan di masa yang akan datang. Penelitian ini bertujuan untuk memetakan penelitian perpajakan pada jurnal online internasional selama tahun 2008 - 2018 atau selama kurang lebih 11 tahun. Periode penelitian dibatasi hanya untuk mengetahui perkembangan topik penelitian yang digunakan. Jenis penelitian adalah kualitatif dengan pendekatan deskriptif. Kualitatif deskriptif diambil karena sesuai dengan tujuan penelitian. Pengambilan data dilakukan dengan studi pustaka dan internet. Data penelitian yang digunakan adalah jurnal online internasional yang telah submit selama 2008 - 2018. Sumber jurnal online internasional meliputi website sciencedirect, proquest, jstor, emeraldinsight, dan website jurnal online internasional lainnya. Hasil pengambilan data diperoleh sebanyak 183 jurnal online penelitian. Berdasarkan hasil analisis yang dilakukan, diperoleh informasi topik penelitian yang meliputi ekonomi, akuntansi, hukum, kebijakan, kepentingan publik, sistem informasi, dan topik lainnya. Topik lain berupa topik penelitian perpajakan selain Pajak Pertambahan Nilai.
\end{abstract}

Kata Kunci: Pemetaan, Pajak Pertambahan Nilai, Multidisiplin, Interdisiplin, Intradisiplin, dan Mind Mapping 


\section{A. PENDAHULUAN}

Penelitian di bidang perpajakan akan terus mengalami perkembangan. Pajak merupakan salah satu disiplin ilmu yang sangat dinamis dan terkait dengan berbagai disiplin ilmu lainnya. Oats (2012) menyatakan bahwa ilmu pajak masih berpotensi untuk berkembang dengan pendekatan disiplin ilmu lainnya sebagai upaya perluasan dan melengkapi penelitian yang ada. Pentingnya pengembangan ilmu pajak dengan menyertakan pendekatan disiplin ilmu lainnya juga diungkapkan oleh McCrudden (2006).

Penelitian yang menggunakan bidang ilmu perpajakan kini semakin berkembang. Winangun (2013) menjelaskan bahwa pajak merupakan cabang disiplin yang sangat luas. Ilmu hukum, ilmu akuntansi dan ilmu ekonomi sangat berkaitan erat dengan pajak. Hubungan yang erat antara ketiga ilmu tersebut diungkapkan oleh Wheatcroft (1997). Ilmu politik dan sosiologi juga berkaitan dengan pajak karena setiap negara mempunyai perbedaan perilaku terhadap pembayaran pajak dan perbedaan metode administrasi pajak, jumlah pemeriksaan pajak, tingkat korupsi, dan perilaku terhadap perencanaan pajak yang agresif (Thuronyi, 2003). Namun, Livingston (1998) menyebutkan bahwa pengunaan ilmu-ilmu tersebut dalam pengembangan ilmu pajak tidak boleh menghilangkan konsep dasar dari ilmu pajak itu sendiri.

Lamb dalam Lamb et. al (2004: 7) memperkenalkan penggunaan interdisipliner dalam pengembangan ilmu pajak dan membagi tema penelitian pajak menjadi dua. Tema penelitian yang pertama berupa tema penelitian pajak yang terkait dengan hukum, ekonomi, akuntansi, ilmu politik, dan kebijakan pemerintah. Tema pertama ini merupakan tema penelitian tradisional atau yang umum digunakan dalam penelitian dahulu. Sedangkan tema yang kedua adalah tema penelitian pajak dengan pendekatan interdisipliner. Tema penelitian pajak yang terkait dengan etika, perilaku, komunikasi, psikologi, strategi bisnis, pasar modal, sistem informasi, dan administrasi publik.

Gentry (2007) menjelaskan mengenai pendekatan yang dapat digunakan dalam suatu penelitian meliputi multidisiplin, interdisiplin, dan intradisiplin. Pendekatan multidisiplin menghadirkan para ahli dari berbagai disiplin ilmu untuk membahas suatu masalah. Masing-masing ahli akan membawa metode atau teknik yang mereka pelajari dari disiplin ilmu masing-masing. Sedangkan pendekatan interdisiplin, penyelesaian suatu masalah diperoleh dari perspektif berbagai disiplin ilmu yang berbeda. Pada pendekatan interdisiplin, metode dan teknik yang dipilih merupakan metode dan teknik yang paling baik dalam penyelesaian masalah.

Masih sangat jarang penelitian yang membahas mengenai pemetaan penelitian mengenai pajak. Penelitian terdahulu lebih membahas mengenai penggunaan pajak dalam penelitian di bidang akuntansi, hukum, dan ekonomi. Beberapa ahli pernah melakukan penelitian mengenai pemetaan penelitian di bidang perpajakan dari beberapa sudut pandang.

Shevlin (2007) meneliti mengenai penelitian pajak yang akan datang dari sudut pandang akuntansi. Penelitian yang dilakukan disesuaikan dengan kompetensi dan pengetahuan penelti sehingga lebih dibatasi pembahasannya pada area akuntansi. Secara umum, penelitian pajak yang dilakukan di bidang akuntansi lebih kepada menjawab tiga pertanyaan utama, yaitu "does taxes matter?", "if not, why not?","if so, how much". Hasil penelitian yang dilakukan oleh Shevlin (2007) menyimpulkan bahwa pendapat apapun untuk penelitian yang akan datang menjadi sering tidak lengkap dan mengabaikan area disiplin selain akuntansi. Hal ini disebabkan gambaran latar belakang pendidikan dan ketertarikan peneliti terhadap suatu bidang tertentu.

Gentry (2007) meneliti penelitian di bidang pajak dari sudut pandang ekonomi. Dalam penelitian perpajakan, Gentry menawarkan tiga perspektif dalam penelitian perpajakan, meliputi multidisiplin, interdisiplin, dan intradisiplin. Masingmasing memiliki kekuatan dan kelemahan terkait penelitian perpajakan. Hasil penelitian menjelaskan bahwa lebih dibutuhkan penelitian dengan pendekatan interdisiplin sehingga dapat memberikan 
competitive advantages bagi penelitian berikutnya.

Berbeda dengan penelitian yang dilakukan oleh Shevlin (2007) dan Gentry (2007), penelitian ini memetakan topik penelitian di bidang Pajak Pertambahan Nilai (PPN) yang ada pada jurnal online internasional selama sepuluh tahun. Pemetaan ini bertujuan untuk mengembangkan topik penelitian di bidang PPN. Setelah dipetakan, diharapkan penelitian yang akan datang mengenai PPN akan menjadi lebih bervariasi dan berkembang pembahasannya.

\section{B. KAJIAN PUSTAKA}

\section{Pemetaan Konsep (Concept Mapping)}

Pemetaan adalah sebuah metode yang digunakan untuk mempermudah seseorang dalam memahami sebuah pengetahuan. Pemetaan dapat digunakan oleh berbagai kelompok usia dan untuk berbagai tujuan. Langkah-langkah yang perlu dilakukan ketika menciptakan pemetaan konsep (concept map) menurut Novak (2010) dan Novak and Canas (2008) terdiri dari mendeskripsikan pertanyaan yang menjadi fokus, mengidentifikasi konsep kunci, mengatur konsep tersebut ke dalam prioritas atau kelompok-kelompok tertentu, menghubungkan kelompok-kelompok tersebut, memperbaiki pengaturan tersebut, menciptakan crosslink, dan ulangi.

Secara sederhana, pemetaan konsep merupakan cara menggambarkan suatu konsep utama secara hirarki. Menurut Carpenito dan Moyet (2007: 6), pemetaan konsep merupakan sebuah teknik berpikir kritis yang berupa diagram untuk menggambarkan hubungan antara suatu konsep atau situasi dengan konsep atau situasi lainnya. Dengan menghubungkan konsep utama dengan konsep lain diharapkan dapat membantu pemahaman konsep utama. Moon, et al (2011) menjelaskan concept mapping mengenai menemukan masalah, melakukan penyederhanaan, melihat kasus atau masalah lain yang serupa, dan mencari penyelesaianya dengan menghubungkan masalah tersebut dengan masalah lain yang serupa dan telah terselesaikan. Dengan demikian, pemetaan konsep dapat dijadikan sebagai sarana untuk penyelesaian masalah.

\section{Pemetaan Pikiran (Mind Mapping)}

Pemetaan pikiran lebih merupakan sebuah konsep yang lebih menekankan gambar dari pada tulisan. Jenis pemetaan ini digambarkan mirip seperti sebuah pohon dengan beberapa cabang. Cabang inilah yang berisi kata kunci. Menurut Rustler dan Tony (2012: 10), mind mapping merupakan sebuah teknik yang dapat dipelajari dan dipraktekkan.

Mind Mapping dapat digunakan dalam berbagai situasi. Beberapa aplikasi yang sering menggunakan teknik ini misalnya bahan presentasi materi perkuliahan, catatan dari buku, catatan dari hasil wawancara/ presentasi/ diskusi, project management, knowledge management, dan persiapan ujian. Mind map harus dapat mencakup keseluruhan, dibuat dengan baik dan dapat dibaca agar tujuan pembuatannya tercapai.

\section{Analisis Isi (Content Analysis)}

Analisis isi merupakan analisis penelitian yang bersifat pembahasan mendalam mengenai isi dari suatu informasi tertulis dalam media massa. Analisis jenis ini biasa digunakan dalam penelitian dengan pendekatan kualitatif. Menurut Berelson (1952: 18), content analysis merupakan sebagai sebuah teknik penelitian untuk menggambarkan konten komunikasi secara objektif, sistematis, dan kuantitatif. Krippendorff (2004: 18) menjelaskan content analysis sebagai teknik penelitian untuk membuat kesimpulan yang dapat direplikasi dan valid dari teks atau materi lainnya sesuai tujuan pembuatannya. Content analysis harus melibatkan prosedur tertentu yang dapat dipelajari dan menyediakan pengetahuan baru sehingga dapat meningkatkan pengetahuan.

\section{METODE PENELITIAN}

Penelitian ini menggunakan pendekatan kualitatif deskriptif. Pendekatan ini digunakan untuk mengetahui tren penelitian Pajak Pertambahan Nilai yang dipublikasikan dalam jurnal internasional online selama sepuluh tahun terakhir. Metode pengumpulan data yang digunakan meliputi Studi Pustaka dan Internet. Analisis data pada penelitian ini adalah analisis data 
kualitatif deskriptif. Analisis kualitatif deskriptif tepat digunakan untuk meneliti masalah-masalah yang membutuhkan studi mendalam yang bertujuan untuk menggambarkan, meringkaskan berbagai kondisi, berbagai situasi, atau berbagai fenomena realitas sosial yang ada di masyarakat yang menjadi objek penelitian dan berupaya menarik realitas itu ke permukaan sebagai suatu ciri, karakter, sifat, model, tanda, atau gambaran tentang kondisi, situasi, ataupun fenomena tertentu (Bungin, 2008:68).

\section{ANALISA DAN PEMBAHASAN}

Berdasarkan data yang dikumpulkan, di tahun 2016 merupakan jumlah penelitian yang terbanyak selama periode penelitian. Penelitian PPN di tahun 2016 didominasi topik mengenai akuntansi, ekonomi, kebijakan, perilaku, psikologi, publik, dan strategi bisnis. Mayoritas penelitian menggunakan perspektif ekonomi dalam pembahasan penelitiannya. Pada tahun 2008, penelitian Pajak Pertambahan Nilai ternyata kurang diminati. Hal ini dapat dilihat dari jumlah penelitian di jurnal online internasional yaitu sebanyak 8 penelitian. Penelitian PPN di tahun 2008 banyak dikaitkan dengan topik meliputi ekonomi, sistem informasi, strategi bisnis, dan topik lainnya. Sama seperti di tahun 2016, mayoritas penelitian menggunakan perspektif ekonomi dalam pembahasannya.

Sebagian besar topik penelitian yang dipublikasikan pada jurnal internasional ada pada topik ekonomi dan kebijakan. Berdasarkan pengolahan data yang dilakukan, jurnal internasional masih sangat jarang membahas topik penelitian berupa etika, komunikasi, dan psikologi. Terdapat beberapa jurnal internasional yang menggabungkan PPN dengan lebih dari satu tema penelitian. Terdapat 3 buah jurnal yang mengaitkan PPN dengan tema penelitian lebih dari satu. Misalnya, mengaitkan PPN dengan hukum dan strategi bisnis dalam satu jurnal penelitian yaitu milik Ainsworth dan Boryana (2012) berjudul "Real-Time Collection of the Value-Added Tax: Some Business and Legal Implications".

Topik penelitian kedua terbanyak adalah kebijakan. Penelitian Pajak Pertambahan Nilai (PPN) yang menggunakan perspektif kebijakan sebanyak 37 penelitian. Sedangkan topik ketiga terbanyak adalah topik selain yang disebutkan. Topik lain ini meliputi kompetisi pajak, cukai, dan penghindaran pajak. Dengan kata lain, topik lain berisi topik penelitian yang lebih ke arah perpajakan selain PPN.

Berdasarkan lokasi pada jurnal internasional yang menjadi data penelitian, lokasi penelitian meliputi benua Afrika, Amerika, Asia, Australia, dan Eropa. Mayoritas penelitian PPN dilakukan di Negara-negara yang ada di Benua Eropa, yaitu sebanyak 35\%. Negara tersebut meliputi Inggris, Serbia, Ireland, Bosnia, Kroasia, Rumania, Republik Ceko, Slovakia, Switzerland, Portugal, dan Yunani.

Sebanyak 45 penelitian atau $25 \%$ dari total jurnal berada di Negara-negara yang ada di Benua Asia. Negara tersebut meliputi China dan India. Penelitian PPN di Indonesia sangat minim sekali yang masuk ke dalam jurnal online internasional. Hal ini terbukti dari tidak ada atau sedikitnya penelitian PPN yang menjadi data penelitian. Dengan demikian masih perlunya penelitian PPN di Indonesia untuk disubmit di jurnaljurnal online internasional.

Saat ini masih jarang penggunaan pendekatan multidisiplin dan interdisiplin pada penelitian perpajakan, khususnya PPN. Kondisi ini sangat memungkinkan untuk penelitian selanjutnya dapat menggunakan pendekatan multidisiplin dan interdisiplin. Shevlin (2007) menjelaskan penelitian perpajakan dari perspektif akuntansi sesuai dengan bidang keahlian yang dimiliki. Pendapat Shevlin (2007) menjadi sangat subjektif dalam penelitian yang dilakukannya. Sedangkan Gentry (2007) menambahkan bahwa penelitian perpajakan dapat menggunakan pendekatan multidisiplin, interdisiplin, dan intradisiplin dalam pembahasan hasil penelitian. Selain itu, penelitian perpajakan dapat dibahas melalui perspektif akuntansi, ekonomi, dan hukum.

McKerchar (2008) menjelaskan bahwa perpajakan merupakan fenomena sosial yang dapat dipelajari melalui berbagai jenis disiplin ilmu. Secara umum, perpajakan akan menarik peneliti dari disiplin ilmu meliputi hukum, akuntansi, 
ekonomi, ilmu politik, psikologi, dan filosofi. Hughes (2016) menjelaskan bahwa aat ini beberapa penelitian menggunakan multidisiplin dan interdisiplin dalam penelitian perpajakan disertai dengan pendekatan metodologi dan bentuk analisis.

Topik penelitian perpajakan tidak hanya terdiri dari hukum, ekonomi, dan akuntansi seperti yang dijelaskan Gentry (2007). Topik penelitian perpajakan dapat dikaitkan pula dengan topik lain seperti kebijakan, kepentingan publik, perilaku, sistem informasi, perilaku, dan topik lain. Topik lain merupakan topik perpajakan selain Pajak Pertambahan Nilai (PPN). Topik tersebut meliputi PPh, Pajak Internasional, cukai, dan Pajak atas Konsumsi.
Topik penelitian dapat dipetakan lagi menjadi sub topik sehingga menjadi semakin berkembang. Akuntansi dapat dibagi menjadi sub topik meliputi akuntansi pajak dan pasar modal. Hukum dapat dibagi menjadi sub topik meliputi penghindaran pajak dan penggelapan pajak. Perilaku dapat dikelompokkan menjadi etika, psikologi, kepatuhan, dan komunikasi. Ekonomi dapat diklasifikasikan menjadi sub topik meliputi ekonomi makro, ekonomi mikro, dan strategi bisnis. Kebijakan dapat diklasifikasi menjadi sub topik berupa fiskal, publik, dan ilmu politik. Kepentingang publik terbagi menjadi administrasi publik dan pelayanan publik.

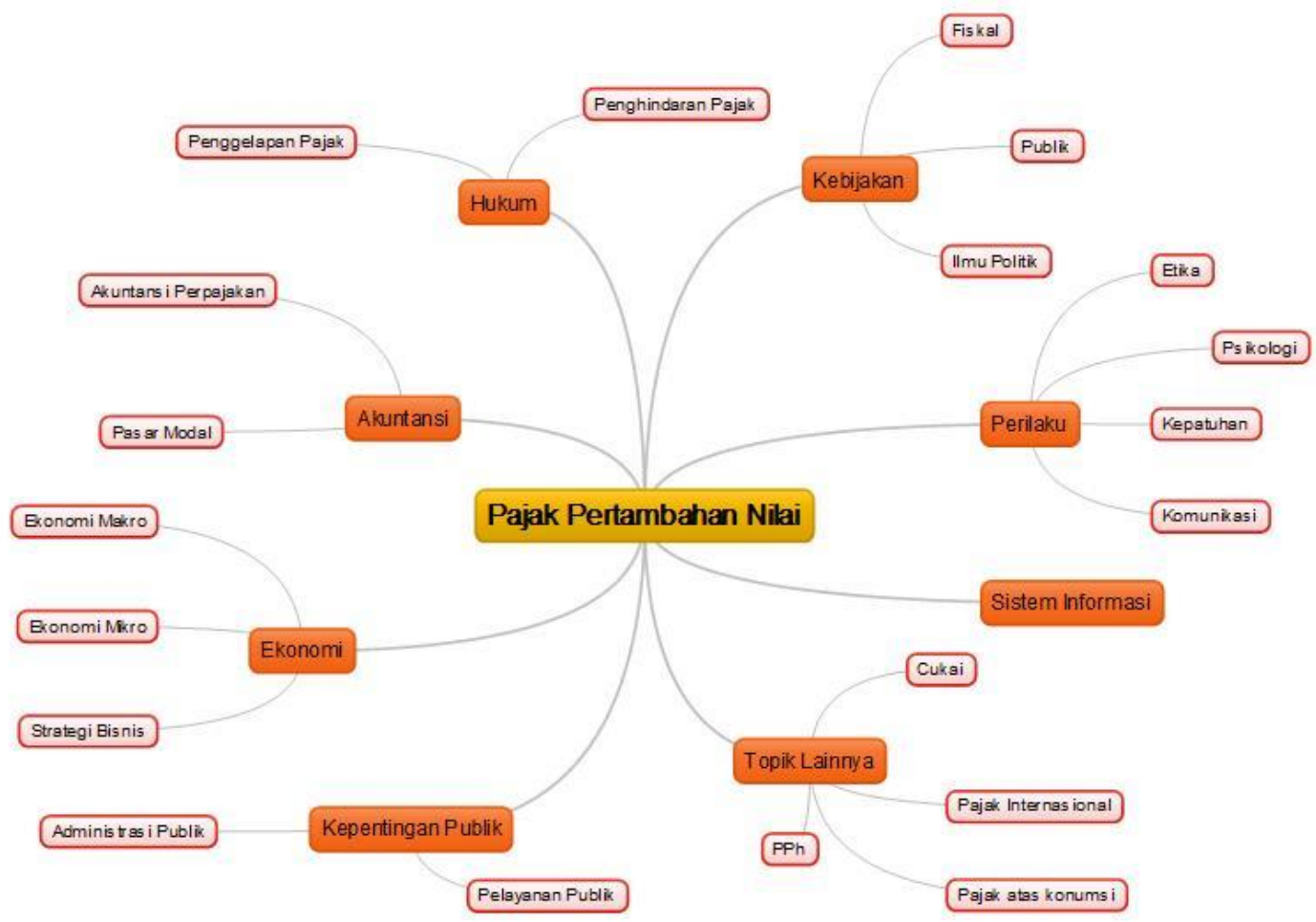

Gambar 1 Mind Map Penelitian Pajak Pertambahan Nilai

Sumber: Data yang Diolah dengan software Mind Mapple Lite

\section{E. KESIMPULAN DAN SARAN \\ 1. Kesimpulan}

Topik penelitian di bidang Pajak Pertambahan Nilai (PPN) semakin berkembang. Hal ini dibuktikan dari semakin variatifnya topik penelitian di bidang PPN selama periode penelitian yaitu sepuluh tahun. Topik penelitian pada jurnal online internasional tidak hanya di bidang akuntansi, ekonomi, dan hukum seperti yang dijelaskan dalam penelitian Shevlin (2007) dan Gentry (2007). Pada jurnal online 
internasional selama 2008 - 2018, topik yang digunakan meliputi administrasi publik, akuntansi, capital market, ekonomi, etika, hukum, ilmu politik, kebijakan, komunikasi, perilaku, psikologi, publik, sistem informasi, dan strategi bisnis. Topik penelitian yang paling sering digunakan dalam penelitian perpajakan adalah mengenai kebijakan. Sedangkan negara yang paling sering melakukan penelitian mengenai Pajak Pertambahan Nilai adalah negara yang berasal dari Benua Eropa.

\section{Saran}

Bagi penelitian selanjutnya diharapkan lebih mengembangkan bidang perpajakan yang akan dipetakan. Dengan demikian hasil penelitian menjadi semakin luas. Penelitian selanjutnya juga dapat memanfaatkan topik-topik yang telah dihasilkan dari penelitian ini. Dengan demikian, penelitian di bidang Pajak Pertambahan Nilai dapat menjadi semakin luas dan bervariasi.

\section{DAFTAR PUSTAKA}

Berelson, B. 1952. Conten Analysis in Communication Research. Glencoe: The Free Press.

Bungin, Burhan. 2001. Metodologi Penelitian Sosial. Surabaya: Universitas Airlangga Press.

Carpenito, Lynda Juall dan Moyet. 2007. Understanding the Nursing Process: Concept Mapping and Care Planning for Students. New Jersey: Lippicott Williams and Wilkins.

Drisko, James dan Tina Maschi. 2016. Content Analysis. New York: Oxford University Press.

Gentry, William M. 2007. The Future of Tax Research: A Mostly Economics Perspective. Journal of the American Taxation Association 29 (2), 95 - 105, 2007.

Hillar, Silvina R. 2012. Mind Mapping with FreeMind. United Kingdom: Packt Publishing.

Hughes, J. Frecknall. 2016. Research Methods in Taxation History. Review of Behavioral Economics, Vol. 3(1), pp. $5-20$.
Krippendorff, Klaus. 2004. Content Analysis: An Introduction to Its Methodology, 2nd edition. United Kingdom: Sage Publishing, Inc.

2013. Content Analysis: An Introduction to Its Methodology, 3rd edition. United Kingdom: Sage Publishing, Inc.

Krisyantono, Rachmat. 2010. Teknik Praktis Riset Komunikasi. Jakarta: Kencana Prenada Media Grup.

Lamb, Margaret; Andrew Lymer; Judith Freedman; dan Simon James. 2004. Taxation: An Interdisciplinary Approach to Research. Oxford University Press.

Lanzing, J. 1997. The Concept Mapping Homepage. Netherlands: University of Twente. www.to.utwente.nl/user/ism/lanzing/ $\underline{\mathrm{cm} \text { home/htm }}$

Livingston, Michael A. 1998. Reinventing Tax Scholarship: Lawyers, Economists and the Role of Legal Academy. Cornell Law Review 83 (1998): 406

Liebowtz, Jay. 2002. Knowledge Mapping: An Essential Part of Knowledge Management. United Kingdom: IRM Press.

McCrudden, C. 2006. Legal Research and the Social Science. Law Quarterly Review 122 (2006): 642 - 645.

McKerchar, M. 2008. Philosophical Paradigms, Inquiry Strategies and Knowloedge Claims: Applying the Principles of Research Design and Conduct to Taxation. eJournal of Tax Research, Vol 6(1), pp. 5-22.

Moon, Brian M., Robert R. Hoffman, Joseph D. Novak, dan Alberto J. Canas. 2011. Applied Concept Mapping: Capturing, Analysing and Organizing Knowledge. United State: Taylor and Francis Group, LLC.

Novak, J. D. dan A. J. Canas. 2008. The Theory Underlying Concept Maps and How to Construct them, Technical Report IHMC CmapTools 
2006-01, Rev. 01-2008. Florida Institute for Human and Mechine Cognition.

2010. Learning, Creating, and Using Knowledge: Concept Maps as Facilitative Tools in School and Corporations, 2nd ed. New York: Routledge.

Oats, L. 2012. Taxation: A Fieldwork Research Handbook. London and New York: Routledge.

Rustler, Florian dan Tony Buzan. 2012. Mind Mapping for Dummies. England: John Wiley and Sons, Ltd.

Shevlin, Terry. 2007. The Future of Tax Research: From an Accounting Professor's Perspective. Journal of the American Taxation Association 29 (2), 87 - 93, 2007.

Thuronyi, Victor. 2003. Comparative Tax Law. The Hague: Kluwer Law International, 2003, 6 . 